\author{
Anita Joanna FAJCZAK-KOWALSKA, PhD \\ Institute of Information Technology, Technical University of Lodz \\ e-mail:afajczak@interia.pl \\ ORCID: 0000-0002-5347-9735
}

\author{
Magdalena Klaudia KOWALSKA, MSc \\ Faculty of Economics and Sociology, University of Lodz \\ e-mail: magdalena.kowalska@uni.lodz.pl \\ ORCID: 0000-0002-5821-0305
}

DOI: $10.15290 /$ oes.2020.01.99.04

\title{
INNOVATIVENESS OF POLISH MANUFACTURING ENTERPRISES IN 2008-2015 ${ }^{1}$
}

\begin{abstract}
Summary
Purpose - The aim of the article is an attempt to estimate the level of innovativeness of Polish manufacturing enterprises conducting their activity in the years 2008-2015.

Research method - The study was divided into three stages. First stage - estimation of synthetic innovativeness indicators of manufacturing enterprises operating in Poland (2008 - 2015) - general and broken down into individual departments of the manufacturing sector. Second stage - estimation of the main descriptive statistics of the synthetic innovativeness indicator of Polish manufacturing enterprises (2008-2015) - average, standard deviation, coefficient of variation, median, minimum value, maximum value. Third stage - creating a ranking of innovativeness of Polish manufacturing enterprises representing individual departments of sector $C$ and conducting their activity in 2015. The ranking was based on a synthetic innovativeness indicator of Polish manufacturing enterprises for 2015.

Results - The study shows that the synthetic index of innovativeness of Polish enterprises in the manufacturing sector in 2009-2015 is characterized by an upward trend. Department C20 came first in the ranking of innovativeness of Polish manufacturing enterprises by individual departments of sector C (manufacturing) operating in 2015, whereas department C13-15 ranked last.

Originality - Estimation, statistical evaluation of the synthetic innovativeness indicator of Polish manufacturing enterprises and creating a ranking of innovativeness of Polish manufacturing enterprises by individual departments of sector C conducting their activity in 2015 .
\end{abstract}

Keywords: innovations, innovativeness of enterprises, manufacturing sector

JEL Classification: L60, O10, O31

${ }^{1}$ Article received on 25 June 2019, accepted on 2 December 2019. 


\section{Introduction}

Modern economy is distinguished by unpredictability and high volatility. Enterprises which want to maintain or improve their competitive position on the market are forced to constantly develop and make changes aimed at modifying individual areas of the company. The company's success depends largely on its ability to adapt to changes: process - new or improved method, product - new or improved product or service, marketing activities - new or improved marketing activities, and organizational activities - new or improved methods of operation.

Innovation is often referred to as introducing changes. These changes can be perceived as indispensable entrepreneurial tools that transform an idea into a specific product, service, process, organizational and marketing activities and, at the same time, influence the development of the enterprise. Without introducing innovations and increasing expenditure on research and development, fast and dynamic development as well as effective functioning of an enterprise are practically impossible. These dependencies are particularly visible in the manufacturing sector, whose state influences the rate of development of the entire economy.

The purpose of the article is an attempt to estimate the level of innovativeness of Polish manufacturing enterprises conducting their activity in 2008-2015. The paper was divided into theoretical part - the essence of innovation and innovativeness of enterprises and practical part - estimation, statistical evaluation of the synthetic innovativeness index of Polish manufacturing enterprises (general index and broken down into individual departments of the manufacturing sector) and creating a ranking of innovativeness of Polish manufacturing enterprises by individual departments of sector C (manufacturing) conducting their activity in 2015.

\section{The essence of innovation and innovativeness of enterprises}

Innovations are an important element of the development of modern enterprises in the conditions of changing environment and development of technology [ $\mathrm{Za}$ stempowski, 2010]. Innovations have an unquestionable impact on socio-economic development as well as the level of competitiveness of enterprises [Misztal, 2017].

The term innovation comes from the Latin "innovatis", meaning "renewing, creating something new". According to the Dictionary of Foreign Words, it means "the introduction of something new, a newly introduced thing, novelty, reform" [Tokarski, 1980].

The concept of innovation was introduced by Schumpeter in 1911. Schumpeter understood innovations as the implementation of new solutions in the sphere of production, the use of new processes or forms of doing business. According to Schumpeter, innovations include "launching a new production method, new goods, opening a new market, discovering a new source of raw materials or introducing a new industry organization" [Schumpeter, 1960]. 
The concept of innovation, considered in the interdisciplinary category, has been precisely analyzed and described by many researchers, using various techniques and methods of conducting research [Duraj, Papiernik-Wojdera, 2010]. In the literature on the subject (both Polish and foreign) we can find numerous definitions of the concept of innovation - considered in narrow and broad terms. Freeman [1994] and Munsfield [1968] introduced a narrow meaning of the term innovation. They described innovation as "the first (in commercial terms) application of an innovative product, process, system or device". A wider approach to the concept of innovation was proposed by Kotler [1994] - "innovation is any product, service or idea that is perceived by someone as new". Fagerberg [2005] described innovations as "new and better than the solutions used by people so far, which have an impact on the socioeconomic conditions of life". Parker [1978] considered innovation as "a process involving all activities bringing a new product or method of production for practical use". Another wide definition of innovation was proposed by Juchniewicz [2011] "introduction of a new or a significantly improved product (or service), process, new marketing method or new organizational method to the work environment or external relations of the organization (such activities can be considered innovative when the product, process, marketing or organizational method is new or significantly improved on the enterprise scale)".

One of the most up-to-date definitions of innovation was presented in 2018 in the OECD manual - "Oslo Manual 2018", in which innovation is defined as "a new or improved product or process (or combination thereof) that differs significantly from the unit's previous products or processes and that has been made available to potential users (product) or brought into use by the unit (process)" [OECD, 2018].

Summarizing the essence and scope of the concept of innovation, considering the opinions of various authors, one can define it as [Baruk, 2002]:

- purposeful and beneficial changes in the current state, which must find practical application (the subject of innovation are products, services, processes, organization, management, marketing methods, market),

- a means of implementing organizational development objectives, a carrier of technical progress, which should result in specific technical, economic and social benefits.

After getting acquainted with the presented definitions of innovation, innovativeness can be described as "demonstrating the ability to generate and implement innovations" [Sikora, Uziembło, 2013]. The basis of the company's innovativeness is searching for sources of new solutions. Innovative activities carried out by enterprises are defined as "a series of scientific (research), financial, technical, commercial and organizational activities aimed at developing or implementing new or significantly improved (from the point of view of the enterprise introducing them) products and processes" [Szymańska, 2012]. 


\section{Purpose and methodology of the study}

The development of modern technologies, globalization processes and the progressing convergence of industries have a significant impact on the functioning and development of enterprises. The effective functioning and development of business entities is conditioned, inter alia, by creating process, product, marketing and organizational innovations [Misztal, 2017]. Manufacturing enterprises play a vital role in many world economies [Dec, Szczerbak, 2015, pp. 215-241]. Manufacturing as an economic sector is the main source of innovation. It stimulates productivity growth, generates jobs and has a considerable share in international trade [Ulbrych, 2017].

The primary objective of the study is an attempt to estimate the level of innovativeness of Polish manufacturing enterprises conducting their activity in 2008-2015.

The data used in the analysis come from the European Statistical Office (Eurostat). The research period is 2008-2015 (the need to narrow the analysis down to such a short period results from the availability of the necessary data for analysis). The survey was based on the Statistical Classification of Economic Activities in the European Community (NACE Rev. 2) - sector C (manufacturing), which includes departments C10 - C33 (table 1).

TABLE 1

Sector $\mathrm{C}$ - manufacturing - the division into departments

\begin{tabular}{|c|c|c|}
\hline \multicolumn{3}{|c|}{ Sector $\mathrm{C}-$ manufacturing } \\
\hline C10-12 & $\begin{array}{l}\text { Manufacture of food } \\
\text { products; beverages } \\
\text { and tobacco products }\end{array}$ & $\begin{array}{l}\text { - production of food (for example: meat, fish, fruit and } \\
\text { vegetables, fats and oils, dairy products, grain mill } \\
\text { products, animal feed, other food products), } \\
\text { - production of beverages (non-alcoholic beverages, } \\
\text { mineral water, alcoholic beverages, mainly obtained by } \\
\text { fermentation, beer and wine, distilled alcoholic } \\
\text { beverages), } \\
\text { - production of tobacco products (tobacco processing, } \\
\text { to a form suitable for direct consumption). }\end{array}$ \\
\hline C13-15 & $\begin{array}{l}\text { Manufacture of } \\
\text { textiles, wearing } \\
\text { apparel, leather and } \\
\text { related products }\end{array}$ & $\begin{array}{l}\text { - production of textiles (for example: fabrics, knitted } \\
\text { fabrics, bed linen, blankets, carpets), } \\
\text { - production of clothing (for example: outerwear and } \\
\text { underwear for women, men, children, work clothes, } \\
\text { casual and formal dress), } \\
\text { - production of leather made of hide (footwear, leather } \\
\text { haberdashery). }\end{array}$ \\
\hline C16-18 & $\begin{array}{c}\text { Manufacture of } \\
\text { wood, paper, printing } \\
\text { and reproduction }\end{array}$ & $\begin{array}{l}\text { - manufacture of wooden products and cork, excluding } \\
\text { furniture (for example: sawmill products, plywood, } \\
\text { veneer, wooden packaging), } \\
\text { - production of paper and paper products, } \\
\text { - printing and reproduction of recorded media (for } \\
\text { example: printing books, newspapers of commercial } \\
\text { forms). }\end{array}$ \\
\hline
\end{tabular}




\begin{tabular}{|c|c|c|}
\hline C19 & $\begin{array}{l}\text { Manufacture of coke } \\
\text { and refined } \\
\text { petroleum products }\end{array}$ & $\begin{array}{l}\text { - production and processing of coke and refined petro- } \\
\text { leum products (processing of crude oil and coal, } \\
\text { production of such products as: coke, petrol, kero- } \\
\text { sene, heating oil, diesel, production of gases such as: } \\
\text { ethane, propane, butane). }\end{array}$ \\
\hline $\mathrm{C} 20$ & $\begin{array}{l}\text { Manufacture of } \\
\text { chemicals and } \\
\text { chemical products }\end{array}$ & $\begin{array}{l}\text { - production of chemicals and chemical products (pro- } \\
\text { cessing of organic and inorganic raw materials as a } \\
\text { result of chemical processes into chemical products). }\end{array}$ \\
\hline $\mathrm{C} 21$ & $\begin{array}{l}\text { Manufacture of basic } \\
\text { pharmaceutical } \\
\text { products and } \\
\text { pharmaceutical } \\
\text { preparation }\end{array}$ & $\begin{array}{l}\text { - production of basic pharmaceutical substances as well } \\
\text { as medicines and other pharmaceutical products. }\end{array}$ \\
\hline $\mathrm{C} 22$ & $\begin{array}{l}\text { Manufacture of } \\
\text { rubber and plastic } \\
\text { products }\end{array}$ & - production of rubber and plastic products \\
\hline $\mathrm{C} 23$ & $\begin{array}{c}\text { Manufacture of other } \\
\text { non-metallic mineral } \\
\text { products }\end{array}$ & $\begin{array}{l}\text { - production of products from other non-metallic mine- } \\
\text { ral materials (for example: glass and glassware, ceramic } \\
\text { products, cement, gypsum) }\end{array}$ \\
\hline $\mathrm{C} 24$ & $\begin{array}{l}\text { Manufacture of basic } \\
\text { metals }\end{array}$ & - metal production \\
\hline C25-30 & $\begin{array}{l}\text { Manufacture of } \\
\text { fabricated metal } \\
\text { products, computer, } \\
\text { electronic and optical } \\
\text { products, electrical } \\
\text { equipment, } \\
\text { machinery, motor } \\
\text { vehicles and other } \\
\text { transport equipment }\end{array}$ & $\begin{array}{l}\text { - manufacture of metal finished products, excluding } \\
\text { machinery and equipment (including manufacture of } \\
\text { weapons and ammunition), } \\
\text { - production of computers, electronic and optical pro- } \\
\text { ducts, } \\
\text { - production of electrical equipment (among others: } \\
\text { devices producing electricity, electricity distribution } \\
\text { and control apparatus, electric lighting equipment), } \\
\text { - manufacture of machinery and equipment, not classi- } \\
\text { fied elsewhere, } \\
\text { - production of motor vehicles, trailers and semi- } \\
\text { trailers, } \\
\text { - manufacture of other transport equipment (vessels } \\
\text { and boats, railway locomotives and rolling stock, air- } \\
\text { craft and spacecraft) }\end{array}$ \\
\hline C31 & $\begin{array}{l}\text { Manufacture of } \\
\text { furniture }\end{array}$ & - furniture production \\
\hline C32 & Other manufacturing & - production of goods, other \\
\hline C33 & $\begin{array}{l}\text { Repair and } \\
\text { installation of } \\
\text { machinery and } \\
\text { equipment }\end{array}$ & $\begin{array}{l}\text { - repair and installation of machines and devices (spe- } \\
\text { cialist repairs, installations and maintenance) }\end{array}$ \\
\hline
\end{tabular}

Source: own elaboration on the basis: [www 1]. 
The study was carried out in three stages.

Stage 1. Estimation of synthetic innovativeness indicators of manufacturing enterprises operating in Poland (2008-2015) - general and broken down into individual departments of the manufacturing sector.

Integrated indicators were calculated taking into account the assumption that the innovativeness of manufacturing enterprises is equal to the sum of partial indicators, based on the formula [Nowak, 1995]:

where:

$$
\mathrm{Sj}=\frac{1}{n} \sum_{i=1}^{n} S_{i j},
$$

$\mathrm{Sj}$ - aggregated meter for $j$-th year,

$\mathrm{n}$ - number of indicators used in the model.

Partial indicators include (stimulants):

$\mathrm{x} 1$ - enterprises [number],

$\mathrm{x} 2$ - turnover or gross premiums written [million euro],

x3 - investment rate (investment/value added at factors cost) [percentage],

$\mathrm{x} 4$ - expenditure on R\&D [million euro],

$\mathrm{x} 5$ - product and process innovation [number],

x6 - organization and marketing innovation [number].

The synthetic innovativeness indicators of manufacturing enterprises operating in Poland consist of the main financial indicators, which, according to the authors, have a significant impact on the level of enterprise innovation - turnover or gross premiums written, investment rate, expenditure on R\&D and indicators selected based on the literature on the subject, defining and determining the types of innovations - product, process, organizational and marketing. The selection and number of indicators was limited due to the availability of data on all departments of the C sector - manufacturing.

Selected diagnostic variables (presented in the form of stimulants) differ in units, therefore it is necessary to normalize the variables - deprivation of variable titres and unification of orders of magnitude in order to achieve comparability. In order to normalize the variables, the unitarization method was applied. The procedure of unitization of variables requires the following formula [Dziekański, 2014]:

- stimulants:

where:

$$
\mathrm{S}=\frac{x_{i j}-\min x_{i}}{\max x_{i}-\min x_{i}},
$$

S, D - normalized value of a characteristic for the examined unit,

$x i j$ - value of the $j$-th feature for the examined unit,

$\max$ - the maximum value of the $j$-th feature,

min - the minimum value of the $j$-th feature. 
Stage 2. Estimation of the main descriptive statistics of the synthetic innovativeness indicator of Polish manufacturing enterprises (2008-2015) - average, standard deviation, median, minimum value, maximum value.

Stage 3. Creating a ranking of innovativeness of Polish manufacturing enterprises by individual departments of sector $\mathrm{C}$ (manufacturing) conducting their activity in 2015 on the basis of a synthetic innovativeness indicator of Polish manufacturing enterprises for 2015.

\section{The result of research}

The survey was carried out on manufacturing sector companies conducting their activity in Poland in 2008 - 2015. The research sample is presented in chart 1 and in table 2. The average number of enterprises in the analyzed period was 179755 . In 2008, 189636 enterprises operated in the manufacturing sector in Poland. In 2015, the number was 187374 (a decrease by 2262 enterprises).

\section{Research sample - sector C (manufacturing)}

\section{CHART 1}

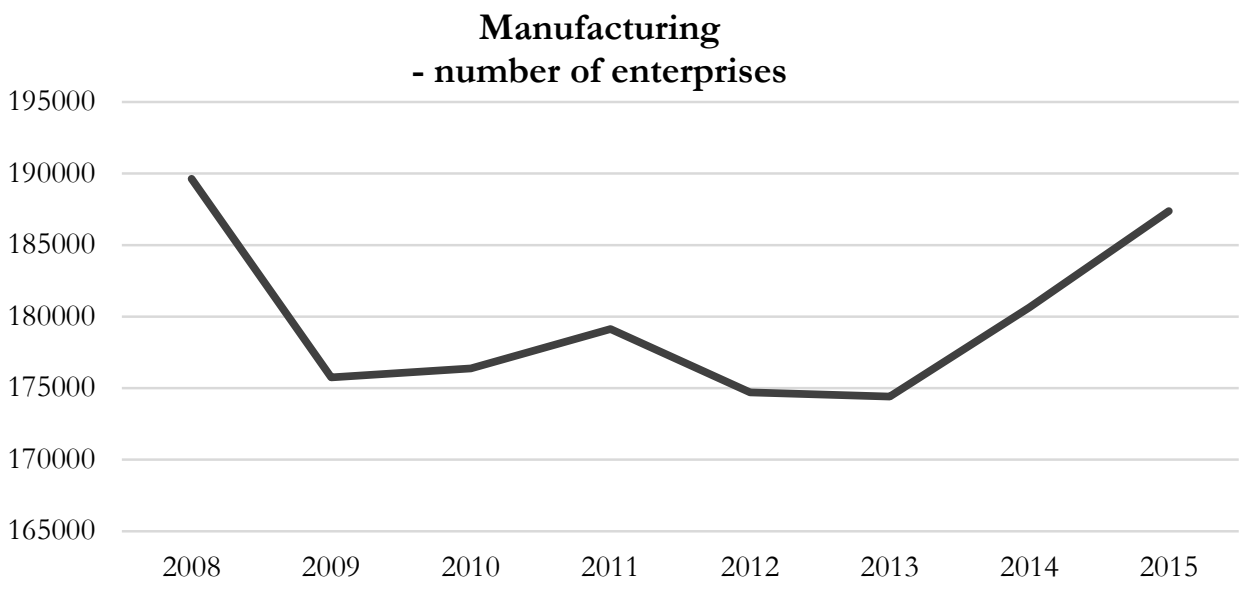

Source: own elaboration on the basis: [www 1].

Taking into account the research period - 2008-2015, the biggest number of enterprises conducted their business in 2015 - department C25-30 - manufacture of fabricated metal products, computer, electronic and optical products, electrical equipment, machinery, motor vehicles and other transport equipment, whereas the smallest number in 2012 - department C19 - manufacture of coke and refined petroleum products. 
TABLE 2

Research sample - sector C (manufacturing) - the division into departments

\begin{tabular}{|c|c|c|c|c|c|c|c|c|c|c|c|c|c|}
\hline \multirow{2}{*}{ Year } & \multicolumn{10}{|c|}{ - number of enterprises } \\
\cline { 2 - 17 } & $\mathbf{C ~ 1 0 - 1 2}$ & C 13-15 & C 16-18 & C 19 & C 20 & C 21 & C 22 & C 23 & C 24 & C 25-30 & C 31 & C 32 & C 33 \\
\hline 2008 & 16060 & 25797 & 32311 & 158 & 2053 & 236 & 8865 & 10860 & 945 & 41574 & 10790 & 13938 & 26049 \\
\hline 2009 & 14254 & 22059 & 27163 & 166 & 2185 & 261 & 7964 & 9922 & 947 & 41196 & 14692 & 13305 & 21644 \\
\hline 2010 & 14281 & 21411 & 28162 & 165 & 2054 & 276 & 8233 & 10028 & 1047 & 40537 & 14336 & 12893 & 22961 \\
\hline 2011 & 13731 & 21200 & 28653 & 146 & 1916 & 294 & 8180 & 9261 & 1217 & 42501 & 14421 & 13085 & 24533 \\
\hline 2012 & 14359 & 19364 & 27556 & 146 & 2004 & 303 & 8044 & 8543 & 1265 & 41874 & 14295 & 12924 & 24023 \\
\hline 2013 & 12661 & 18567 & 27206 & 175 & 2126 & 330 & 8034 & 8840 & 1263 & 41161 & 14390 & 13249 & 26412 \\
\hline 2014 & 13137 & 20059 & 27999 & 175 & 2202 & 341 & 7896 & 8766 & 1296 & 43766 & 14802 & 13920 & 26280 \\
\hline 2015 & 14578 & 19740 & 28195 & 176 & 2221 & 329 & 8371 & 9190 & 1363 & 46537 & 16105 & 13369 & 27200 \\
\hline Total & $\mathbf{1 1 3 0 6 1}$ & $\mathbf{1 6 8 1 9 7}$ & $\mathbf{2 2 7 2 4 5}$ & $\mathbf{1 3 0 7}$ & $\mathbf{1 6 7 6 1}$ & $\mathbf{2 3 7 0}$ & $\mathbf{6 5 5 8 7}$ & $\mathbf{7 5 4 1 0}$ & $\mathbf{9 3 4 3}$ & $\mathbf{3 3 9 1 4 6}$ & $\mathbf{1 1 3 8 3 1}$ & $\mathbf{1 0 6 6 8 3}$ & $\mathbf{1 9 9 1 0 2}$ \\
\hline
\end{tabular}

Source: own elaboration on the basis: [www 1].

As a result of the study, synthetic innovativeness indicators of manufacturing enterprises operating in Poland (2008-2015) were obtained, broken down into individual departments of manufacturing sector (table 3). Integrated indicators can take values from 0 to 1 (the higher the level of the indicator, the higher the level of innovativeness of the company).

TABLE 3

Synthetic indexes of innovativeness of manufacturing sector - Poland (2008-2015)

\begin{tabular}{|l|c|c|c|c|c|c|c|c|c|c|c|c|c|}
\hline \multirow{2}{*}{ Year } & \multicolumn{8}{|c|}{ Synthetic indexes of innovativeness of manufacturing sector - Poland } \\
\cline { 2 - 17 } & C 10-12 & C 13-15 & C 16-18 & C 19 & C 20 & C 21 & C 22 & C 23 & C 24 & C 25-30 & C 31 & C 32 & C 33 \\
\hline 2008 & 0.590 & 0.678 & 0.509 & 0.331 & 0.472 & 0.419 & 0.613 & 0.734 & 0.521 & 0.424 & 0.598 & 0.613 & 0.588 \\
\hline 2009 & 0.551 & 0.484 & 0.271 & 0.143 & 0.323 & 0.156 & 0.245 & 0.496 & 0.293 & 0.255 & 0.417 & 0.298 & 0.437 \\
\hline 2010 & 0.443 & 0.279 & 0.150 & 0.300 & 0.361 & 0.295 & 0.348 & 0.516 & 0.386 & 0.471 & 0.377 & 0.412 & 0.471 \\
\hline 2011 & 0.252 & 0.226 & 0.354 & 0.379 & 0.341 & 0.468 & 0.357 & 0.435 & 0.453 & 0.503 & 0.353 & 0.408 & 0.484 \\
\hline 2012 & 0.367 & 0.129 & 0.193 & 0.498 & 0.413 & 0.694 & 0.270 & 0.349 & 0.391 & 0.458 & 0.450 & 0.505 & 0.461 \\
\hline 2013 & 0.328 & 0.145 & 0.412 & 0.715 & 0.533 & 0.611 & 0.335 & 0.269 & 0.440 & 0.294 & 0.388 & 0.313 & 0.300 \\
\hline 2014 & 0.505 & 0.373 & 0.498 & 0.731 & 0.585 & 0.638 & 0.433 & 0.327 & 0.706 & 0.451 & 0.454 & 0.637 & 0.418 \\
\hline 2015 & 0.453 & 0.384 & 0.557 & 0.857 & 0.882 & 0.872 & 0.570 & 0.584 & 0.615 & 0.721 & 0.711 & 0.577 & 0.575 \\
\hline
\end{tabular}

Source: own elaboration on the basis: [www 1].

The highest value of the integrated index of innovativeness of enterprises in the manufacturing sector in Poland can be observed in the departments (table 3):

- $\quad$ C20 - manufacture of chemicals and chemical products - 0.882 (2015),

- $\quad$ C21 - manufacture of basic pharmaceutical products and pharmaceutical preparation - 0.872 (2015),

- $\quad$ C19 - manufacture of coke and refined petroleum products - 0.857 (2015). 
The lowest value of the integrated index of innovativeness of enterprises in the manufacturing sector in Poland can be observed in the departments (table 3):

- C13-15 - manufacture of textiles, wearing apparel, leather and related products -0.129 (2012),

- C19 - manufacture of coke and refined petroleum products - 0.143 (2009),

- C13-15 - manufacture of textiles, wearing apparel, leather and related products -0.145 (2013).

In 2015, compared with 2008, the largest decrease in innovativeness of manufacturing enterprises in Poland can be seen in department C13-15 - manufacture of textiles, wearing apparel, leather and related products -0.294 (from 0.678 in 2008 to 0.384 in 2015), while the largest increase was recorded in department C19 0.529 (from 0.331 in 2008 to 0.857 in 2015).

The individual integrated innovativeness indicators of enterprises in the manufacturing sector conducting their activities in Poland in 2008-2015 enabled the creation of a synthetic indicator of innovativeness in Polish enterprises in the manufacturing sector (2008-2015). Taking into account the results of the study, the synthetic indicator of innovativeness of Polish enterprises in the manufacturing sector (2008-2015), is characterized by an upward trend in 2009-2015 (table 4).

TABLE 4

Synthetic indicator of innovativeness of manufacturing sector - Poland (2008-2015)

\begin{tabular}{|c|c|}
\hline Year & $\begin{array}{c}\text { Synthetic indicator of innovativeness of manufacturing sector } \\
\text { - Poland }\end{array}$ \\
\hline 2008 & 0.545 \\
\hline 2009 & 0.336 \\
\hline 2010 & 0.370 \\
\hline 2011 & 0.386 \\
\hline 2012 & 0.398 \\
\hline 2013 & 0.391 \\
\hline 2014 & 0.520 \\
\hline 2015 & 0.643 \\
\hline
\end{tabular}

Source: own elaboration on the basis: [www 1].

Table 5 presents the main descriptive statistics of the synthetic innovativeness indicator of Polish enterprises in the manufacturing sector (2008-2015). The average value of the indicator was 0.449 . The average deviation of the measurement results from the average - standard deviation is 0.107 , calculating the average, we are wrong by 0.107 . The coefficient of variation was 0.238 , which means average variability. The middle value was 0.336 , while the minimum and the maximum value were 0.336 and 0.643 respectively (table 5). 
TABLE 5

Descriptive statistics of synthetic indicator of innovativeness of manufacturing sector - Poland

\begin{tabular}{|c|c|c|c|c|c|c|}
\hline \multirow{2}{*}{ Synthetic indicator } & \multicolumn{5}{|c|}{ Descriptive statistics } \\
\cline { 2 - 7 } & Average & Median & Min & Max & $\begin{array}{c}\text { Standard } \\
\text { deviation }\end{array}$ & $\begin{array}{c}\text { Coefficient } \\
\text { of variation }\end{array}$ \\
\hline $\begin{array}{l}\text { Synthetic indicator of innova- } \\
\text { tiveness of manufacturing } \\
\text { sector - Poland }\end{array}$ & 0.449 & 0.395 & 0.336 & 0.643 & 0.107 & 0.238 \\
\hline
\end{tabular}

Source: own elaboration on the basis: [www 1].

In the final stage of the study, based on the synthetic innovativeness indicator of Polish manufacturing enterprises for 2015, a ranking of innovativeness of Polish manufacturing enterprises by individual departments of sector $\mathrm{C}$ (manufacturing) operating in 2015 was created. The first position in the ranking of innovativeness of Polish manufacturing enterprises by individual departments of sector C (manufacturing) operating in 2015 is held by department C20 - manufacture of chemicals and chemical products, while the last one is held by department C13-15 - manufacture of textiles, wearing apparel, leather and related products (table 6 ).

TABLE 6

Ranking of innovativeness of Polish manufacturing enterprises by individual departments of sector C (manufacturing) operating in 2015

\begin{tabular}{|l|c|c|}
\hline \multicolumn{3}{|c|}{ Ranking of innovativeness of Polish manufacturing enterprises (2015) } \\
\hline 1 & C 20 & 0.882 \\
\hline 2 & C 21 & 0.872 \\
\hline 3 & C 19 & 0.857 \\
\hline 4 & C 25-30 & 0.721 \\
\hline 5 & C 31 & 0.711 \\
\hline 6 & C 24 & 0.615 \\
\hline 7 & C 23 & 0.584 \\
\hline 8 & C 32 & 0.577 \\
\hline 9 & C 33 & 0.575 \\
\hline 10 & C 22 & 0.570 \\
\hline 11 & C $16-18$ & 0.557 \\
\hline 12 & C $10-12$ & 0.453 \\
\hline 13 & C $13-15$ & 0.384 \\
\hline
\end{tabular}

Source: own elaboration on the basis: [www 1]. 


\section{Conclusions}

The study was conducted on manufacturing sector companies operating in Poland in the years 2008-2015. Their average number in the analyzed period was 179755.

As a result of the study, synthetic innovativeness indicators of manufacturing enterprises operating in Poland in the years 2008-2015 were obtained (general indicator and indicators broken down into individual departments of the manufacturing sector).

Taking into account the average results of synthetic innovativeness indicators of manufacturing enterprises operating in Poland (2008-2015) divided into individual departments of the manufacturing sector, department C21 - manufacture of basic pharmaceutical products and pharmaceutical preparation is characterized by the highest level of innovativeness, while the lowest level of innovativeness is displayed by department C13-15 - manufacture of textiles, wearing apparel, leather and related products. Thus, a conclusion can be drawn that the most innovative department of sector C (manufacturing) is department C21 - manufacture of basic pharmaceutical products and pharmaceutical preparation, which is characterized by the highest level of innovation.

The individual integrated innovativeness indicators of enterprises in the manufacturing sector conducting their activities in Poland in 2008-2015 enabled the creation of a synthetic indicator of innovativeness of Polish enterprises in the manufacturing sector - 2008-2015. The synthetic indicator of innovativeness of Polish manufacturing enterprises operating in 2008-2015 is characterized by an upward trend, which should be viewed as a positive phenomenon.

Considering the created ranking of innovativeness of enterprises in the manufacturing sector operating in Poland in 2015, department C20 - manufacture of chemicals and chemical products is characterized by the highest degree of innovativeness, while the lowest degree of innovativeness is displayed by department C13-15 - manufacture of textiles, wearing apparel, leather and related products.

Based on the research, the innovativeness of Polish sector C (manufacturing) enterprises can be assessed as average (the average value of the index was 0.449), characterized by a tendency to increase. The most innovative department of sector C in 2008-2015 is department C21 - manufacture of basic pharmaceutical products and pharmaceutical preparation, while the least innovative department is C13-15 manufacture of textiles, wearing apparel, leather and related products.

\section{References}

Baruk J., 2002, Innowacje, kultura innowacyjna i poziom innowacyjności przedsiebiorstw przemystonych, „Gospodarka Narodowa”, nr 11-12, s. 78-84.

Dec P., Szczerbak M., 2015, Specyfika rachunkowości i ocena kondycii przedsiebiorstwa przemystowego, [w:] Przedsiebiorstwo przemystowe w Polsce, Poniatowska-Jaksch M., Sobiecki R. (red.), Oficyna Wydawnicza Szkoła Główna Handlowa w Warszawie, Warszawa. 
Duraj J., Papiernik-Wojdera M., 2010, Przedsiębiorczość i innowacyjność, Difin, Warszawa.

Dziekański P., 2014, Koncepcja wską̧nika syntetycznego oceny poziomu rozৃwoju gmin wiejskich województwa śmietokryzskiego w warunkach globalizacji, „Zeszyty Naukowe Szkoły Głównej Gospodarstwa Wiejskiego w Warszawie. Problemy Rolnictwa Światowego", t. 14(29), z. 3, s. 61-70.

Fagerberg J., 2005, Innovation a guide to the literature, DOI: 10.1093/oxfordhb/978019 9286805.003.0001, http://www.oxfordhandbooks.com/view/10.1093/oxfordhb/9780199286805.001.0001/oxfordhb-9780199286805-e-1 [date of entry: 24.04.2019].

Freeman Ch., 1994, The economics of technical change, "Cambrige Jurnal of Economics", vol. 18, iss. 5, pp. 463-514.

Juchniewicz M., 2011, Innowacje nietechnologiczne w przemyśle sposiywcsym, „Roczniki Naukowe SERiA", t. XIII, nr 2, s. 159-164.

Kotler P., 1994, Marketing. Analiza, planowanie, wdrażanie i kontrola, Gebethner \& Ska, Warszawa.

Mansfield E., 1968, Industrial Research and Technological Innovation, WW Norton, New York.

Misztal A., 2017, Otwarte innowacje w polskich przedsiebiorstwach - ewaluacja, „Zeszyty Naukowe Małopolskiej Wyższej Szkoły Ekonomicznej w Tarnowie”, t. 33, nr 1, s. 27-37.

Nowak E., 1995, Rachunkowość menedżerska, Wydawnictwo Akademii Ekonomicznej im. Oskara Langego we Wrocławiu, Wrocław.

Parker J., 1978, The economics of innovation. The national and multinational enterprise in technological change, Longman, London.

Schumpeter J., 1960, Teoria rozwoju gospodarczego, PWN, Warszawa.

Sikora J., Uziębło A., 2013, Innowacja w przedsiębiorstwie - próba żefiniowania, „Zarządzanie i Finanse", t. 2, nr 2, s. 351-376.

Szymańska A., 2012, Innowacyjnośc produktowa przedsiebiorstw produkcyjnych a preferencje konsumentów, „Prace Komisji Geografii Przemysłu Polskiego Towarzystwa Geograficznego", nr 20, s. 147-161.

Tokarski J., 1980, Stownik wyrazón obcych, PWN, Warszawa.

Ulbrych M., 2017, Gtówne tendencje w rozwoju handlu zagranicznego wyrobami polskiego przetwórstwa przemystowego, „Horyzonty Polityki”, nr 8(22), s. 151-167, DOI: 10. 17399/HP.2017.082208.

Zastempowski, M., 2010, Uwarunkowania budowy potencjału innowacyjnego polskich matych $i$ średnich przedsiebiorstw, Wydawnictwo Naukowe Uniwersytetu Mikołaja Kopernika, Toruń.

www 1, https://ec.europa.eu/eurostat/ramon/nomenclatures/index.cfm?TargetUrl $=$ LST_NOM_DTL\&StrNom=NACE_REV2\&StrLanguageCode $=$ PL\&IntPcKe $\mathrm{y}=18512354 \&$ StrLayoutCode=HIERARCHIC [date of entry: 24.04.2019].

www 2, https://read.oecd-ilibrary.org/science-and-technology/oslo-manual-2018_ 9789264304604-en\#page27 [date of entry: 14.09.2019]. 